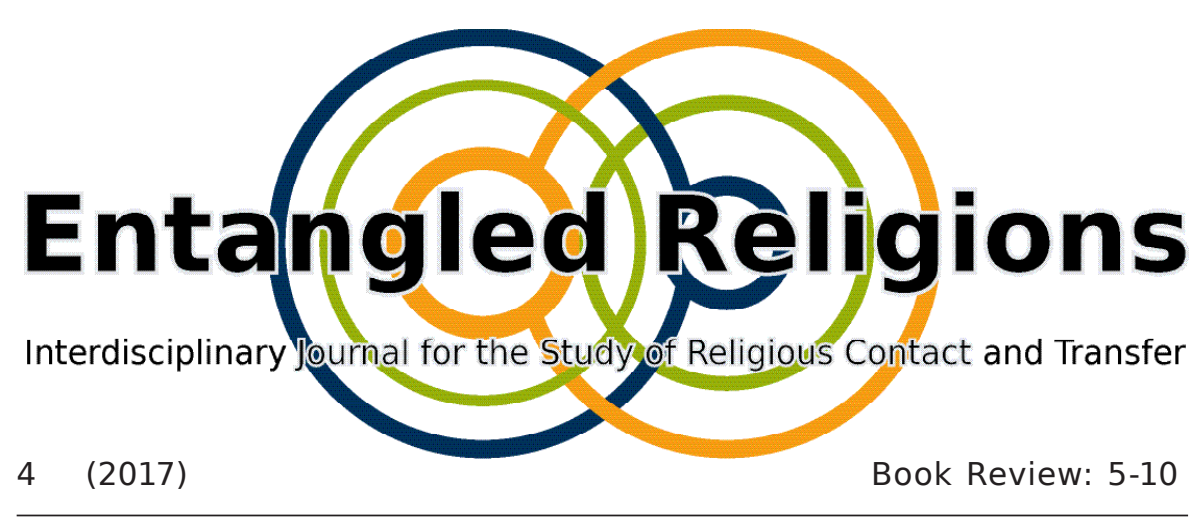

\title{
Disability and World Religions: An Introduction
}

Edited by Darla Y. Schumm and Michael Stolzfus.

Waco: Baylor University Press, 2016.

258 pp., £44.95, ISBN (hardcover) 978-1-48-130521-1.

REVIEW BY: MICHEL CLASQUIN-JOHNSON \& MARY G. CLASQUIN-JOHNSON

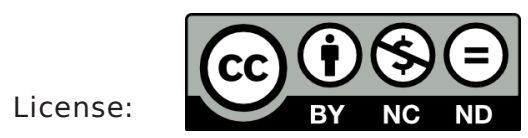

This contribution to Entangled Religions is published under the Creative Commons Attribution-NonCommercial-NoDerivatives 4.0 International Public License (CC BY-NC-ND 4.0 International). The license can be accessed at http://creativecommons.org/licenses/ by-nc-nd/4.0/ or is available from Creative Commons, 559 Nathan Abbot Way, Stanford, California 94305, USA.

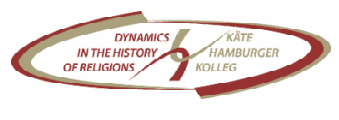

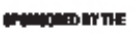




\title{
Disability and World Religions: An Introduction
}

\author{
Edited by Darla Y. Schumm and Michael Stolzfus. \\ Waco: Baylor University Press, 2016. \\ 258 pp., f44.95, ISBN (hardcover) 978-1-48-130521-1. \\ REVIEW BY: MICHEL CLASQUIN-JOHNSON \& MARY G. CLASQUIN-JOHNSON
}

This book is an attempt to find a synergy between two disciplines that have historically not found much space for collaboration: the study of religion on the one hand, and the study of disability on the other. Hence the very apposite subtitle "An Introduction". That immediately raises the question: Who is competent to review it? Should it be reviewed by a Religious Studies scholar, or by a specialist in Disability Studies? In this case, it will be both. By reviewing the book from these respective points of view we will attempt to show the value of the book from our respective professional perspectives, then bring a joint summary and evaluation to the table.

The editors specifically claim that this book could serve as a textbook for students in either discipline, and this is the lens we will use to look at the volume from our respective disciplines.

\section{Religious studies}

Religion forms the framework of the book: instead of chapters like "Visual disability and religion" we instead see titles like "Judaism and disability" 
and so on. This leaves open the possibility of a companion volume organized the other way round.

To be more specific, we see chapters on the attitude towards disability in, and the contributions that can be made by, Hinduism (Amy Donahue), Buddhism (Stephen E. Harris), Confucianism (Benjamin Lukey), Daoism (Andrew Lambert), Judaism (Julia Watts Belser), Catholicism (May Jo Iozzio), Protestantism (Thomas Reynolds), Islam (Vardit Rispler-Chaim), and Indigenous Traditions in the Western Hemisphere (Lavonna Lovern).

Let us start by saying that each of the respective chapters expresses a specific religion's understanding of how that religion approaches the issue of disability. Some of these religious traditions have explicitly addressed the issue of disability, making the chapter author's job a little easier. Other traditions have remained largely silent on the issue, forcing the chapter author to cherry-pick among the rare examples in the tradition's scriptures, and/or fall back on the tradition's first principles to construct a theology of disability from scratch. Regardless, all the contributors have acquitted themselves well. They received a brief, and have written engaging, wellstructured essays within the limits set by that brief.

Each chapter follows a broadly similar pattern. It starts with a short introduction to the history and fundamental beliefs and practices of the religion in question. Then follows a review of that aspect of Disability Studies most relevant to the religion in question. The chapter concludes with a suggestion of how the religion can respond to the disability issue. Some, though not all, also pay attention to the question of what has actually been done by the religion in terms of support for people living with disabilities, before considering what more it can do. Specialists in a specific religion may question the specifics of a chapter - the chapter on Hinduism, for example, relies a little heavily on the work of the controversial Wendy Doniger. In the larger picture, however, the contributors cannot be faulted. 
If we have no quarrel with the individual chapters, the same is not true of the book as a whole. In the title, we see the term "world religions", and this term is used several times in the Preface. There is no awareness here that the very term has recently been called into question, or that there is colonial baggage attached to it. We do not believe, as some do, that the term itself should be abandoned, but critical awareness on this point would enhance the book.

At the other end of the book, what is sorely missing is a chapter to bring it all together. If we have discussed the religions separately, is there nothing more to be said? Is it possible at all to create a tentative synthesis from these chapters, to speak of the position towards disability by religion itself? And if this is not possible, that too is a significant finding that should be reported and critically discussed.

Even within the World Religions paradigm, there are inconsistencies that reflect the book's probable North American market. Christianity is privileged by receiving separate chapters on Catholicism and Protestantism, but where is Orthodox Christianity, and where are the more modern Christian offshoots like Mormonism? The equally deep subdivisions in Buddhism and Islam do not get granted the distinction of separate chapters. The Baha'i Faith is conspicuous in its absence, as is the current revival of Paganism. The chapter on Western Hemisphere Indigenous Traditions is a welcome addition, but then where is the chapter on African, or Afro-Diasporic, traditions? The chapter division therefore reflects a view of religion that is both parochial and outdated. It does not reflect the vibrant developments in religion and the study of religion that we have seen in the last half-century.

This does not make it impossible to recommend this book as an introductory text in the study of religion. It should be noted, though, that such usage would need to be accompanied by much critical comment by the lecturer and complementary material. 


\section{Disability Studies}

Disability Studies situates disability as a contested social, cultural and political occurrence. This has influenced a host of international policies related to disability such as the Convention on the Rights of Persons with Disabilities (2006), which has 160 signatories. Central to these policies has been the adoption of the principles of human rights, social justice and inclusion.

In the South African context, these principles have also formed the basis of educational policies in post-apartheid South Africa. While there is raging debate related to whether it is possible to influence and alter beliefs, attitudes and ultimately practice, this book provides deeper insight into how people in general makes sense of disability, drawing upon religious beliefs and traditions. We cannot mandate what matters and therefore we must seek to understand the policy-practice gap.

This book deepened our understanding of why policy implementation is so difficult as well as the value of approaching disability from the perspective of religious beliefs. The chapter on "Hinduism and Disability" provides a theoretical understanding of the concept of karma, particularly how the beliefs it shaped in ancient India have persisted in modern India.

Similarly, in the chapter on "Buddhism and Disability", the discussion on Buddhist texts illustrates how disability is represented as the "negative results of past karmic actions..." while illuminating the concepts of impermanence and suffering. Iozzio's chapter on "Catholicism and Disability" as well as Belser's chapter on "Judaism and Disability" highlight widespread exclusionary practices. It would be essential to add a chapter on African Religions and Disability to better understand disability in our context. Finally, leaders of religious communities could be key in influencing how 
their communities understand and embrace disability in contemporary society.

\section{Conclusion}

This is a book for the student rather than the subject specialist. Scholars of religion, and indeed experts on disability, will find themselves slogging through too much well-known introductory material. When a book is designed as a student textbook, inevitably it gets slanted towards a certain market. In this case that market is North American. From a South African perspective, using it in either discipline would require several addenda on local religious and disability-related conditions. We suspect that the same would be true from other non-North American perspectives.

But the book does set forward a framework for studying religion from a fresh perspective. By focusing on the religious response to disability, it shows a new way to introduce the stale "world religions" trope as a human phenomenon. Similarly, it can be used to introduce the world of disability in a different way than the dominant biomedical approach. Religion and disability are deeply human phenomena. By combining them and teasing out their relations, the book shows us a potentially exciting new way to teach religion and disability as human sciences.

This book has its flaws. It is not the final word on religion and disability. But it is the first, and it opens up new paths.

\section{MICHEL CLASQUIN-JOHNSON / MARY G. CLASQUIN-JOHNSON}

